Published by Al-Nahrain College of Medicine P-ISSN 1681-6579

E-ISSN 2224-4719

Email: iraqijms@colmed-alnahrain.edu.iq

http://www.colmed-alnahrain.edu.iq

http://www.iraqijms.net

Iraqi JMS 2018; Vol. 16(2)

\title{
Effect of Stick Sweet Cherry Extracts (Prunus (SP)) on Some Biochemical Markers in Albino Mice and Biological Activities in Different Types of Bacteria
}

\author{
Maysoon M.N.M. Saleem MSC
}

Biotechnology Division, Applied Science Department, University of Technology, Baghdad, Iraq

\begin{abstract}
Background The sweet cherry (Prunus avium L) has a wide variety of secondary metabolites, which has biochemical and biological activity and used as potential source of a drug. There is no data published on stick cherry extract effect on enzymes activities, kidney function test, inflammatory marker and minerals. As well as on antimicrobial activity of stick cherry extract for inhibition the growth of pathogenic bacteria of different types.

Objective To illustrate the effect of ethanolic stick sweet cherry extract on serum enzyme activities; lactate dehydrogenase (LDH), aspartate transaminase (AST), creatine kinase (CK) and the concentration of urea, uric acid, creatinine, C-reactive protein (CRP) also potassium, calcium in serum of albino mice as well as to investigate antimicrobial activity of the extract to inhibit the growth of different types of pathogenic bacteria.

Methods A total of 28 albino mice were classified into three groups, the first control group (G1) consist of 8 animals treated with $0.2 \mathrm{ml} /$ day distilled water, second group (G2) comprised of 10 animals treated with $30 \mathrm{mg} / \mathrm{Kg} / \mathrm{day}$ of stick cherry extract, third group (G3) formed of 10 animals treated with $100 \mathrm{mg} / \mathrm{Kg} /$ day of extract.

Results There was statistically significant reducing effect in serum enzyme activities of LDH, CK $(P<0.001)$ at 30 and 100 $\mathrm{mg} / \mathrm{Kg} / \mathrm{day}$, and significant change in serum AST at low and high concentration. There is remarkable change in concentration of urea, uric acid, creatinine and increase in potassium and calcium $(P<0.001)$. The result of antimicrobial activity of stick sweet cherry extracts show inhibition the growth of pathogenic bacteria, different types which involves; (Pseudomonas aeruginosa, Escherishia coli, Staphylococcus aureus, Proteus vulgarweris, Serratiam arcescens). This indicates that the chloroform extract was active against the most pathogenic bacteria at all the concentration used and was more than ethanol extracts.

Conclusion Orally administration of sweet stick cherries extracts to albino mice animals caused a potential difference in different biochemical parameters, enzyme activities, LDH, AST, CK, concentration of urea, uric acid and creatinine, C-reactive protein. Those are risk factors for different diseases, inflammatory, oxidative stress, heart disease. This could be minimized or prevented by polyphenols of cherries stick extract.

Keywords Citation Prunus, Creatine kinase, Sweet cherry, CRP, Potassium, Escherichia coli

Saleem MNMN. Effect of Stick Sweet Cherry Extracts (Prunus (SP)) on some biochemical markers in Albino Mice and Biological Activities in Different Types of Bacteria. Iraqi JMS. 2018; 16(2): 114-124. doi: 10.22578/IJMS.16.2.2
\end{abstract}

List of abbreviations: AST = Aspartate transaminase, CRP $=$ Creactive protein, $\mathrm{CK}=$ Creatine Kinase, $\mathrm{LDH}=$ Lactate dehydrogenase

\section{Introduction}

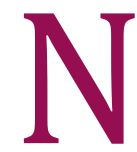

umerous

bioactive

chemical compounds of plants are found in dietary sources such as fruits, vegetable, herbs, the plants medicinal value is related to their phytochemical components, which produce definite physiological actions on human body. The most important of these components are a wide variety of secondary metabolites such as alkaloids, flavonoids, tannins, terpenoides, and phenolic compounds which have been found in vitro to have antimicrobial properties (1). The sweet cherry (Prunu savium $L$ ) are among the most delicious fruit, it is also known popularly as the "super fruit" because of its low in calories, high 
antioxidants, which have significant health benefits and provide good immunity against numerous diseases ${ }^{(2,3)}$. Pharmacological and biochemical effects exhibited by anthocyanins tart cherry have been recommended as nutritional supplements or chemopreventive agents ${ }^{(4)}$. The biological action mechanism predominantly is thought to result from enzyme inhibition, antioxidant activity, scavenge free radicals (5). Cherry contain sensible amounts of anthocyanins in addition to other bioflavonoids such chlorogenic acid, gallic acid, p-coumaric acid kaempferol, quercetin, hydroxycinnamates, cyanidins; all are potent antioxidants, and have characteristic anti-inflammatory via inhibition of cyclooxygenase activities (6). The skin phenolic compounds are contributed to sensory and fruits organoleptic qualities such as astringency and taste ${ }^{(7)}$. Cherry are rich in dietary fibers, generous intake of dietary fiber reduces risk of developing the following diseases: coronary heart disease, lowers blood pressure and appears to improve immune function ${ }^{(5,8)}$. Numerous other studies show that other cherries phenolic compounds reducing atherogenicity ${ }^{(9)}$. Cherries contain several polyphenols antioxidants, anthocyanins and cyanidin that possess many biological activities, anticancer, antidiabetic, and antiinflammation, antiobese properties ${ }^{(10,11)}$. Also decreased risk for atherosclerosis, and other metabolic syndrome of heart disease ${ }^{(6,12)}$, and other diseases or protective effects on neuronal cells (13). Anthocyanin of cherry pigment and bioflavonoid, after consumption transferred to human body, helps to generate essential amino acid and play vital in protection of body cells $(10,11)$. Cherries contain oxidized form vitamin $C$ dehydroascorbic acid ${ }^{(14)}$, and it contain both hydro soluble, vitamins $B$ and liposoluble vitamins $E, K$ and also characterized by presence of higher content of beta carotene vitamin A, folate and to a lower extent zeaxantine and lutein. Cherries also contain minerals such as calcium, magnesium, phosphorous, potassium and iron (15,16).
Consumption of cherry in healthy women has been observed to reduce uric acid levels circulation and improve symptoms gout that include reduction in symptoms associated with gout, and many inflammatory diseases and provide good immunity against numerous diseases by regulation of circulating inflammatory markers (17). Inflammatory substance in blood, C-reactive protein, associated with an increased heart disease risk. It was suggested modulatory selective effect of cherries on C-reactive protein (CRP), such effects may be essential for prevention and management inflammatory diseases ${ }^{(18)}$. Its production also occurs in macrophages, neurons, kidneys, in atherosclerotic lesions by smooth muscle cells and adipose tissue and pulmonary alveoli (19). CRP is a critical component of the immune system a complex protein that our body make when faced with a major infection or trauma, it depends on genetics as well as lifestyle habits ${ }^{(19)}$.

Herbals, fruits, and spices because of their antimicrobial effect they are of interest due to their possible use as alternatives to food preservatives, apart from being the primary source of food some nutrients essential, fruits and vegetables also contain a variety of bioactive components, which might have other health beneficial (7). Previously it was observed that the kind and amount of the leaves of Prunus Laurocerasus $L$ cherry leaves extracts have a significant effect against tested fungi of different types by using Six different extracts ( 4 solvent extracts and 2 water extracts) were used to determine the antifungal effect by disc diffusion and micro dilution methods (20).

Despite the high number of publications that document plants extracts of antimicrobial activity against different species of fungi, none of reports have concerned with stick sweet cherry extract (Prunu savium).

To our knowledge there is no studies on the effect of stick sweet cherry extract on enzymes activities lactate dehydrogenase (LDH), aspartate transaminase (AST), Creatine kinase (CK), and concentrations of urea, uric acid, 
creatinine, potassium and calcium and CRP as well as on the inhibition of different types of pathogenic bacteria growth to find antimicrobial activity which involves; (Pseudomonas aeruginosa, Escherichia coli, Staphylococcus aureus, Proteus vulgaris, Serratia marcescens). Therefore, the aim of the recent work was to investigate the effect of stick cherries extract on this biochemical parameter in blood serum of white albino mice evaluation of antimicrobial activity to inhibit growth of pathogenic bacteria of different types.

\section{Methods}

\section{Extraction of stick cherry}

Stick sweet cheery (Prunus avium L) were collected, purified and air dried at room temperature then grinding to powder, prepared for extraction. The powder was extracted by weighting of $35 \mathrm{gm}$ of crushed stick cherries and adding $400 \mathrm{ml}$ of $70 \%$ ethanol in soxhulate at boiling degree for seven hours and with slow continuous mixing and then filtrate the extract in the rotary evaporation until getting a thick solution. At room temperature drying the solution for 2-3 days until it become a crushed dried and was dissolved in distilled water to prepared two different concentrations $30 \mathrm{mg} / \mathrm{Kg}, 100 \mathrm{mg} / \mathrm{Kg}$ for the measurement of biochemical parameter.

\section{Laboratory animals}

From Animal House Production Unit of Biotechnology Division, University of Technology, albino mice were obtained, A total of 28 healthy albino mice weighting (15-35 gm) aged of 2-3 months were used in this study. The animals were divided into three main groups: The first group (G1) contained 8 animals, served as the control which received distilled water, while the second group (G2) contained 10 animals, which treated with an oral administration of $0.2 \mathrm{ml} /$ day of stick cherry extract at $30 \mathrm{mg} / \mathrm{kg} /$ day concentration for a period of 21 days, and the third group (G3) contained 10 animals, which treated with an oral administration of $0.2 \mathrm{ml} /$ day of stick sweet cherry extract at $100 \mathrm{mg} / \mathrm{Kg} /$ day for 21 days. After three weeks of receiving of the extract, the mice were sacrificed in the morning by decapitation. The blood sample were collected by cardiac puncture with disposable syringe, withdraw into plain tube and the taken blood was left for 15 minutes at room temperature for clotting, centrifugation and separated serum were used for the measurement of enzymes activities, LDH, AST, CK, urea, uric acid, creatinine, potassium, calcium, CRP at the same day of collection. Biochemical assay Serum enzyme activities of AST, CK, was determined by spectrophotometer using kit method. Urea, uric acid, creatinine, potassium, calcium and CRP levels were measured by spectrophotometer.

\section{Extraction method of stick cherry extract for evaluation of antimicrobial activity}

For extraction of stick cherry powder two solvents were used, chloroform and $70 \%$ ethanol solvent by using soxhlet, in experimental study for evaluation of antimicrobial activity of stick sweet cherry extract to find the inhibitory effect of pathogenic bacteria growth. The dried extract was diluted with distilled water for ethanol, chloroform extract used to yield the final concentration $(5,10,25$, and 50,100$) \mathrm{mg} / \mathrm{ml}$ of both solvent to test for the antimicrobial activity of plant extract.

Plant extract antibacterial activity was determined by using an agar-well diffusion assay (21). Bacterial samples obtained from (Biotechnology Branch/University of Technology) where testing was conducted used for the assays. Five strains bacterial were used in present study, they were Escherichia coli, Pseudomonas aeruginosa, Proteus vulgaris, Staphylococcus aureus, Serratia marcescens. The suspension cell culture was adjusted by comparing against 0.4-0.5 McFarland scale standard. For the investigation of the antimicrobial activity, the suspensions $(0.1 \mathrm{ml})$ of target strain were spread on the plates. To allow reproduction of the results or further detailed analysis of the strains used the isolates 
were kept in culture. The antibacterial activity of the crude plant extracts was cultures were grown on nutrient broth and then inoculated onto Muller - Hinton agar for testing. Following the initial incubation, organisms were suspended in saline solution and their concentration equilibrated. Each sample was transferred onto Muller - Hinton agar by using a sterile cotton swab. The well diameter was 8 $\mathrm{mm}$ and distilled water were applied as control for ethanol extract samples and ethanol was applied as control for chloroform extract samples. Plates were incubated over night at $37{ }^{\circ} \mathrm{C}$, for $24 \mathrm{hrs}$, the inhibition zone was appearing around well measured and recorded the results. The plate crude extract showing the activity were considered as antibacterial activity, the dried extract was diluted with distilled water for the sample of ethanol extract and with ethanol for the sample of chloroform extract to yield the final concentration.

\section{Statistical analysis}

All the result was expressed as the mean $\pm S D$. Statistically all data grouped were evaluated with SPSS/10.5 software. Hypothesis of testing method included one-way analysis of variance (ANOVA) followed by the least significant difference (LSD) test; $P$ values of less than 0.05 were considered to indicate statistical significance.

\section{Results}

The present investigation tested the efficacy of the oral administration of $0.2 \mathrm{ml} /$ day stick sweet cherry extract for period of three weeks on the activities of enzymes, LDH, AST, CK, and kidney function assessment, urea, uric acid, creatinine, as well as potassium, calcium and CRP in serum of albino mice at two different doses, $30 \mathrm{mg} / \mathrm{Kg} / \mathrm{day}$ and $100 \mathrm{mg} / \mathrm{Kg} / \mathrm{day}$, as illustrated in tables 1, 2 and 3. The effect of stick sweet cherry extract on the activities of, LDH, AST, and CK in serum of albino mice, were represented in table 1 , the mean $\pm S D$ values of serum LDH, AST and CK activities were very highly significantly decreased in treated animals at $30 \mathrm{mg} / \mathrm{Kg} /$ day and as compared to untreated animal group, $(P<0.001, P<0.001$, $\mathrm{P}<0.001)$ respectively. Significant reduction in the activities of LDH, AST and CK $(P<0.001$, $\mathrm{P}<0.01, \quad \mathrm{P}<0.001)$ at concentration 100 $\mathrm{mg} / \mathrm{Kg} /$ day in treated animal with extract as compared to untreated respectively.

Table 2 illustrated the effect of oral administration of stick sweet cherry extract on concentration of urea, uric acid, creatinine, it shows significant reduction in concentration of urea, uric acid and creatinine $(P<0.001)$ at both extract concentration $30 \mathrm{mg} / \mathrm{Kg} /$ day and 100 $\mathrm{mg} / \mathrm{Kg} /$ day respectively in comparison with untreated animal.

Table 1. Effect of stick cherry extract on the activities of, LDH, AST, CK in serum of mice

\begin{tabular}{cccc}
\hline $\begin{array}{c}\text { Parameters } \\
\text { (U/L) }\end{array}$ & $\begin{array}{c}\text { Untreated Group } \\
(\mathbf{n = 8 )}(\mathbf{G 1})\end{array}$ & $\begin{array}{c}\text { Treated extract with } \\
\mathbf{3 0} \mathbf{~ m g / K g / d a y} \\
(\mathbf{n = 1 0 )}(\mathbf{G 2})\end{array}$ & $\begin{array}{c}\text { Treated extract with } \\
\mathbf{1 0 0} \mathbf{~ m g} / \mathbf{K g} / \text { day } \\
(\mathbf{n = 1 0 )}(\mathbf{G 3})\end{array}$ \\
\hline LDH & $933.66 \pm 59$ & $717.54 \pm 48^{*}$ & $581 \pm 43^{*}$ \\
AST & $34.45 \pm 5.2$ & $27.5 \pm 2.7^{* *}$ & $23.5 \pm 2.4^{*}$ \\
CK & $105 \pm 9$ & $70.0 \pm 4.5^{*}$ & $50.0 \pm 3.2^{*}$ \\
\hline
\end{tabular}

*Very highly significant decrease at $\mathrm{P}<0.001,{ }^{* *}$ highly significant decrease at $\mathrm{P}<0.01$ (parameters as means $\pm \mathrm{SD}$ ) 
Table 2. Effect of stick cherry extract on, uric acid, urea, creatinine in mice serum

\begin{tabular}{|c|c|c|c|}
\hline $\begin{array}{l}\text { Parameters } \\
\text { (mg/dL) }\end{array}$ & $\begin{array}{l}\text { Untreated Group } \\
\qquad(n=8)(G 1)\end{array}$ & $\begin{array}{c}\text { Treated extract with } \\
30 \mathrm{mg} / \mathrm{Kg} / \mathrm{day} \\
(\mathrm{n}=10)(\mathrm{G} 2)\end{array}$ & $\begin{array}{c}\text { Treated extract with } \\
100 \mathrm{mg} / \mathrm{Kg} / \text { day } \\
(\mathrm{n}=10)(\mathrm{G})\end{array}$ \\
\hline Urea & $39.6 \pm 4.3$ & $28.3 \pm 3.2^{*}$ & $24.4 \pm 1.7^{*}$ \\
\hline Uric acid & $5.5 \pm 0.96$ & $3.33 \pm 0.38^{*}$ & $2.9 \pm 0.30 *$ \\
\hline Creatinine & $15.1 \pm 0.8$ & $9.1 \pm 0.7^{*}$ & $6.4 \pm 0.4^{*}$ \\
\hline
\end{tabular}

*Very highly significant decrease at $\mathrm{P}<0.001$, (parameters as means $\pm \mathrm{SD}$ )

Table 3 revealed the effect of oral of treated group $(P<0.001, P<0.001)$ at both administration stick sweet cherry extract on potassium, calcium, and CRP, there was statistically significant decrease in the extract concentration $30 \mathrm{mg} / \mathrm{Kg} /$ day and 100 $\mathrm{mg} / \mathrm{Kg} /$ day respectively in comparison with untreated animal. concentration of potassium, calcium, and CRP

Table 3. Effect of stick sweet cherry extraction, Potassium, Calcium, and C-reactive protein in serum of albino mice

\begin{tabular}{|c|c|c|c|}
\hline Parameters & $\begin{array}{l}\text { Untreated Group } \\
\qquad(n=8)(G 1)\end{array}$ & $\begin{array}{c}\text { Treated extract with } \\
30 \mathrm{mg} / \mathrm{Kg} / \text { day } \\
(\mathrm{n}=10)(\mathrm{G} 2)\end{array}$ & $\begin{array}{l}\text { Treated extract with } \\
100 \mathrm{mg} / \mathrm{Kg} / \text { day } \\
(\mathrm{n}=10)(\mathrm{G} 3)\end{array}$ \\
\hline $\begin{array}{l}\text { Potassium } \\
(\mathrm{mmol} / \mathrm{L})\end{array}$ & $4.7 \pm 0.38$ & $7.68 \pm 0.29 *$ & $9.4 \pm 0.24^{*}$ \\
\hline $\begin{array}{l}\text { Calcium } \\
(\mathrm{mg} / \mathrm{dL})\end{array}$ & $9.02 \pm 0.2$ & $11.56 \pm 032 *$ & $12.4 \pm 0.42 *$ \\
\hline $\begin{array}{l}\text { C-reactive } \\
\text { protein } \\
(\mathrm{mg} / \mathrm{L})\end{array}$ & $8.4 \pm 1.28$ & $5.3 \pm 1.1 * *$ & 3. $8 \pm 0.87 * *$ \\
\hline
\end{tabular}

The inhibition zone of chloroform of stick (Prunus) ethanol extract against pathogenic cherry extract (Prunus) was shown in table $4 . \quad$ bacteria in table 5.

The inhibition zone of stick sweet cherry

Table 4. The inhibition zone of chloroform of stick cherry extract (Prunus)

\begin{tabular}{cccccc}
\hline \multicolumn{6}{c}{ Diameter of inhibition zone $(\mathbf{m m})$} \\
\hline $\begin{array}{c}\text { Concentration } \\
\mathbf{m g} / \mathbf{m l}\end{array}$ & $\begin{array}{c}\text { Escherichia } \\
\text { coli }\end{array}$ & $\begin{array}{c}\text { Pseudomonas } \\
\text { aeruginosa }\end{array}$ & $\begin{array}{c}\text { Proteus } \\
\text { vulgaris }\end{array}$ & $\begin{array}{c}\text { Staphylococcus } \\
\text { auruus }\end{array}$ & $\begin{array}{c}\text { Serratia } \\
\text { marcescens }\end{array}$ \\
\hline 5 & 6 & 4 & 9 & 4 & 0 \\
10 & 8 & 12 & 16 & 12 & 0 \\
25 & 9 & 14 & 16 & 14 & 9 \\
50 & 11 & 14 & 16 & 14 & 9 \\
100 & 14 & 14 & 16 & 17 & 9 \\
\hline
\end{tabular}

The diameter of well $(8 \mathrm{~mm})$ the upper results without the diameter of well. (0) means no inhibition zone 
Table 5. The Inhibition zone of ethanol stick sweet cherry extract (Prunus)

\begin{tabular}{cccccc}
\hline \multicolumn{6}{c}{ Diameter of inhibition zone $(\mathbf{m m})$} \\
\hline $\begin{array}{c}\text { Concentration } \\
\mathbf{m g} / \mathbf{m l}\end{array}$ & $\begin{array}{c}\text { Escherichia } \\
\text { coli }\end{array}$ & $\begin{array}{c}\text { Pseudomonas } \\
\text { aeruginosa }\end{array}$ & $\begin{array}{c}\text { Proteus } \\
\text { vulgaris }\end{array}$ & $\begin{array}{c}\text { Staphylococcus } \\
\text { auruus }\end{array}$ & $\begin{array}{c}\text { Serratia } \\
\text { marcescens }\end{array}$ \\
\hline 5 & 0 & 0 & 4 & 0 & 0 \\
10 & 0 & 0 & 4 & 0 & 4 \\
25 & 0 & 0 & 5 & 0 & 4 \\
50 & 8 & 8 & 8 & 0 & 8 \\
100 & 9 & 9 & 8 & 7 & 12 \\
\hline
\end{tabular}

The diameter of well $(8 \mathrm{~mm})$ the upper results without the diameter of well. (0) means no inhibition zone

Result clearly demonstrated that the stick cherry chloroform extract was active against the most types of pathogenic bacteria types at all the concentration used and was more activity formed than ethanol extract as in figure 1 and figure 2.

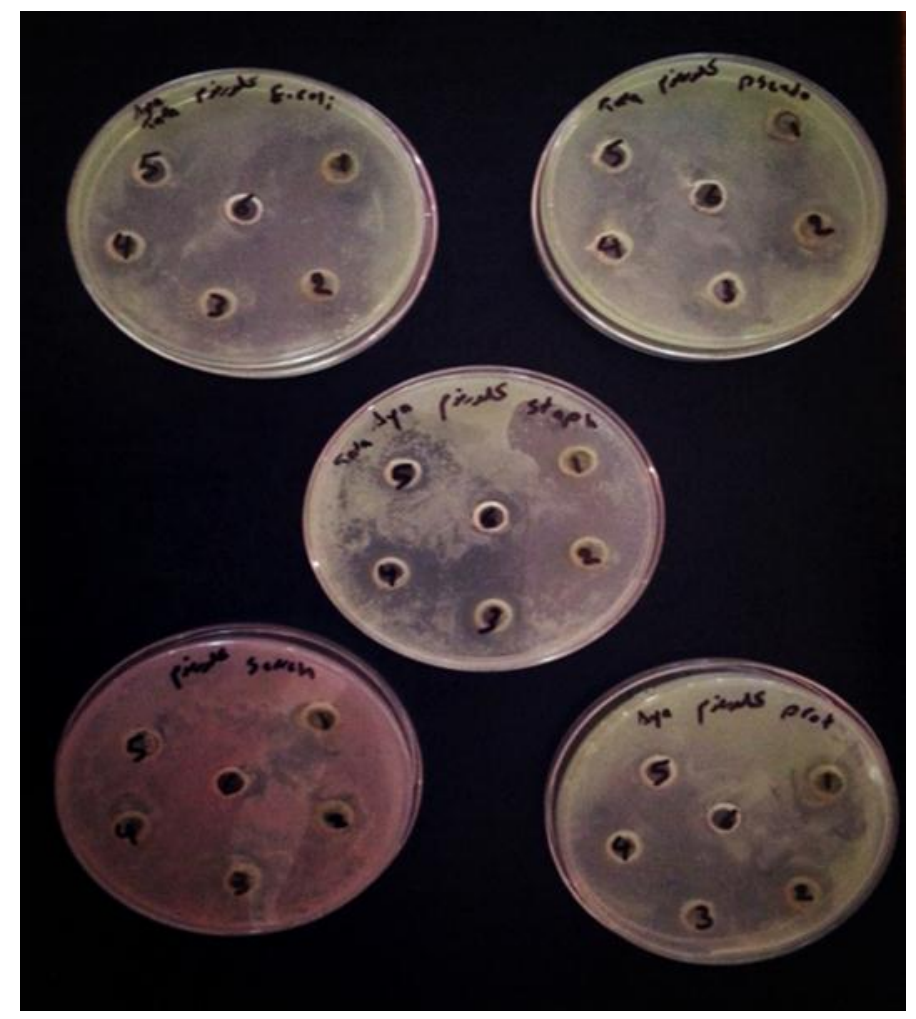

Figure 1. The inhibition zone of chloroform stick sweet cherry extracts (prunus)) against pathogenic bacteria. Plate in the upper right Pseudomonas aeruginosa, plate in the upper left $E$. coli, plate in the center Staphylococcus aureus, plate in the lower right Proteus vulgaris, plate in the lower left Serratia marcescens. Well No.1: The concentration of prunus chloroform extract $100 \mathrm{mg} / \mathrm{ml}$. Well No. 2: The concentration of prunus chloroform extract $50 \mathrm{mg} / \mathrm{ml}$. Well No. 3: The concentration of prunus chloroform extract $25 \mathrm{mg} / \mathrm{ml}$. Well No. 4: The concentration of prunus chloroform extract $10 \mathrm{mg} / \mathrm{ml}$. Well No. 5: The concentration of prunus chloroform extract $5 \mathrm{mg} / \mathrm{ml}$. Well No. 6: The control Ethanol 


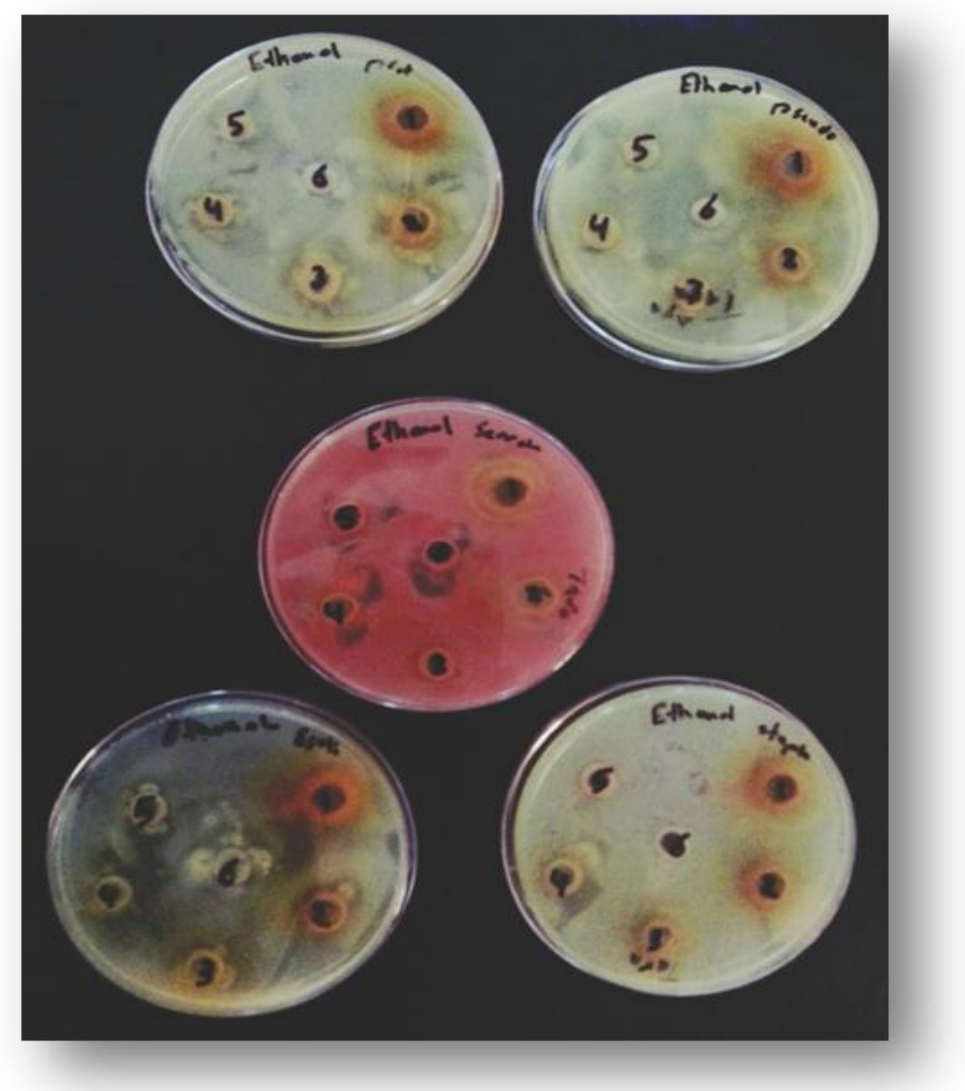

Figure 2. The inhibition zone of stick sweet cherry (Prunus) Ethanol extract against pathogenic bacteria. Plate in the upper right Pseudomonas aeruginosa, plate in the upper left E. coli, plate in the center Staphylococcus aureus, plate in the lower right Proteus vulgaris, plate in the lower left Serratia marcescens. Well No.1: The concentration of prunus ethanol extract $100 \mathrm{mg} / \mathrm{ml}$.

Well No. 2: The concentration of prunus ethanol extract $50 \mathrm{mg} / \mathrm{ml}$. Well No. 3: The concentration of prunus ethanol extract $25 \mathrm{mg} / \mathrm{ml}$. Well No. 4: The concentration of prunus ethanol extract $10 \mathrm{mg} / \mathrm{ml}$. Well No. 5: The concentration of prunus ethanol extract $5 \mathrm{mg} / \mathrm{ml}$. Well No. 6: The control distilled water

\section{Discussion}

Cherries are loaded with diseases fighting antioxidant, and contain a great number of anthocyanins, constituents that possess strong antioxidant, anti-inflammatory activities, and anti-aging properties (22). The present study illustrated significant reduction in the activities of LDH, AST and CK at concentration 30, and $100 \mathrm{mg} / \mathrm{Kg} /$ day in treated animal with extract as compared to untreated table 1 . This change in serum enzyme activity is due to polyphenol bioactive compounds in cherry that may offer protection against heart disease and metabolic syndrome due enhancement in blood vessels health (16). The observed decreased value in LDH activity was 1.30 at extract concentration
$30 \mathrm{mg} / \mathrm{Kg} /$ day and 1.60 at concentration 100 $\mathrm{mg} / \mathrm{Kg} /$ day times lower than upper normal limit. The reduced value in AST activity was 1.25 at concentration of $30 \mathrm{mg} / \mathrm{Kg} /$ day and 1.46 at concentration $100 \mathrm{mg} / \mathrm{Kg} /$ day times lower than upper normal limit and the value for CK activity was 1.5 at extract concentration $30 \mathrm{mg} / \mathrm{Kg} /$ day and 2.1 at concentration 100 $\mathrm{mg} / \mathrm{Kg} /$ day times lower than the upper normal limit. This may be explained that in tart cherries bioactive compounds found beneficially inhibit certain enzymes activities (2) while others boosting (23) and enhance primary antioxidants ${ }^{(24)}$. Anthocyanins scavenge free radicals directly, in a number of ways: protect the body against oxidative damage by binding 
to DNA and activate detoxification and antioxidant enzyme systems in the body. Anthocyanins cherry have been shown to protect brain cells and blood vessels against oxidative stress, implying that consumption cherry may help to prevent formation of plaque atherosclerotic and diseases of neurodegenerative ${ }^{(12,14)}$.

Result in table 2 show statistically significant reduction in concentrations of urea, uric acid and creatinine at both concentration 30 $\mathrm{mg} / \mathrm{Kg} /$ day and $100 \mathrm{mg} / \mathrm{Kg} /$ day of stick cherry extract in comparison with untreated animal, this could be attributed to the presence of antioxidants and phytochemical compound, it was demonstrated that cherries constituents; anthocyanins flavanols, phenols, inhibiting inflammation, and provide protection against cell injury ${ }^{(11,14,25)}$. The observed decreased value of urea in serum level at $30 \mathrm{mg} / \mathrm{Kg} / \mathrm{day}$ and $100 \mathrm{mg} / \mathrm{Kg} /$ day were 1.4 and 1.6 times lower than the upper normal limit respectively. The observed reduced value of creatinine in serum level at 30 and $100 \mathrm{mg} / \mathrm{Kg} /$ day were 1.66 and 2.35 times lower than the upper normal limit respectively. Some studies suggest that cherries fruits have anti-inflammatory benefits that may relieve the pain of arthritis and gout, associated with higher risks disease of cardiovascular and mortality (26,27). The observed decreased value of serum uric acid level at $30 \mathrm{mg} / \mathrm{Kg} /$ day and $100 \mathrm{mg} / \mathrm{Kg} /$ day was1.65 and 1.9 times lower than the upper normal limit respectively. In previous studies it has been observed that consumption of cherry fruit lowers serum uric acid level and plasma creatinine in healthy human subjects and animals $(17,28)$, this is in agreement with our result on stick cherries but there is no report on stick sweet cherry. It was reported that sweet cherries selectively and significantly were found to reduce a number of biomarkers associated with inflammatory diseases (29). These findings suggesting that cherries may possess the capacity of lowering urate production through reducing tubular reabsorption and/or increasing the glomerular filtration rate ${ }^{(29)}$. In an animal study, intake of diet rich cherry in rats with hyperuricemia significantly decreased the levels of serum uric acid by inhibiting of xanthine oxidase and xanthine dehydrogenase of hepatic activity (28), cherries may also have anti-inflammatory properties against the series of inflammatory responses triggered by urate monosodium crystals $(26,30)$.

Table 3 demonstrates significant reduction in the concentration of potassium, calcium, and CRP of treated group at both concentration 30 $\mathrm{mg} / \mathrm{Kg} /$ day and $100 \mathrm{mg} / \mathrm{Kg} /$ day in comparison with untreated animal, this is due to differences in human genetic, could lead to differences in metabolic clearance and absorption between individuals, in addition to differences in intestinal microorganism populations (31). The observed increased value for potassium in serum level at $30 \mathrm{mg} / \mathrm{Kg} / \mathrm{day}$, $100 \mathrm{mg} / \mathrm{Kg} / \mathrm{day}$ was 1.63 and 2 times higher than the upper normal limit respectively. Increasing of potassium intake has a direct effect on preventing cerebrovascular accident, independent of its effect on blood pressure through a variety of mechanism (32). The observed increased value for calcium in serum level at 30 and $100 \mathrm{mg} / \mathrm{Kg} /$ day was 1.28 and 1.37 times higher than the upper normal limit respectively. Low absorption or high excretion of calcium, causes osteoporosis because the maintenance of the plasma calcium concentration is more important to the organism, for neuromuscular ${ }^{(33)}$. The present data on C-reactive protein shows significant reduction in treated animal with extract at both does $30 \mathrm{mg} / \mathrm{Kg} /$ day and $100 \mathrm{mg} / \mathrm{Kg} /$ day compared with untreated group table 3 . The reduction of CRP has been observed in treated animals with cherry extract also this been linked to atherosclerosis and heart disease (30). In atherosclerosis, or cholesterol plaguing of the arteries, is known to have an inflammatory component that is thought to cause a change in CRP levels in the blood, and this is depending on genetics as well as lifestyle habits ${ }^{(19)}$. The compounds found in cherries modulate numerous pathways to protect against other conditions associated with inflammation including cancer, cardiovascular disease, metabolic syndrome ${ }^{(2,34)}$. Change in CRP may be useful for the detection of systemic inflammatory processes to assess treatment of 
bacterial infections with antibiotics to differentiate between active and inactive forms of disease infection (19).

In conclusion, orally administration of sweet stick cherries extract to animals caused a potential difference in the enzyme activities, LDH, AST, CK, concentration of urea, uric acid and creatinine $\mathrm{C}$-reactive protein those are risk factors for different diseases, which lead to increased inflammation, and oxidative stress and which may be prevented by the polyphenols and phytochemical compound or minimized in stick cherries extract. To test the clinical relevance of our findings, future studies need to be performed with large number of animal.

In the previous study, the in vitro antifungal activities of the $P$. laurocerasus $L$. leaf extracts against the fungi and their activity potentials were qualitatively and quantitatively assessed by the presence or absence of inhibition zones and zone diameters, minimum inhibitory concentration (MIC) and minimum bactericidal concentration (MBC) ${ }^{(20)}$. Several studies have been conducted to understand the mechanism of action of different plant extracts and essential oils (35). There is no report on the inhibition of pathogenic bacteria growth by stick sweet cherry extracts, therefore the antimicrobial activity of stick cherry extract was evaluated for inhibition the growth of pathogenic bacteria. Result clearly demonstrated that the stick cherry chloroform extract was active against the most types of pathogenic bacteria types at all the concentration used and was more activity formed than ethanol extract. Highest inhibition found that the chloroform and ethanol illustrated the more activity at concentration $100 \mathrm{mg} / \mathrm{ml}$.

The highest inhibition zone for Escherichia coli was $14 \mathrm{~mm}$ when chloroform extract was used $100 \mathrm{mg} / \mathrm{ml}$ and the lower was $6 \mathrm{~mm}$ as in table 4 and figure 1 . For ethanol extract the highest inhibition zone in the same bacteria (E. coli) was $9 \mathrm{~mm}$ at ( $100 \mathrm{mg} / \mathrm{ml}$ extract) table 5 and figure 2. For Pseudomonas aeruginosa the highest inhibition yields when we using chloroform extract in the concentration (25, $50,100) \mathrm{mg} / \mathrm{ml}$ the diameter of inhibition zone was $14 \mathrm{~mm}$ and the lower inhibition zone at the concentration $(5,10) \mathrm{mg} / \mathrm{ml}$ with diameter $4 \mathrm{~mm}, 12 \mathrm{~mm}$ respectively, while for ethanol extract the highest inhibition was $(50,100)$ $\mathrm{mg} / \mathrm{ml}$ diameter $8 \mathrm{~mm}, 9 \mathrm{~mm}$ respectively, but there was no inhibition zone at the concentration $\quad(5,10,25) \mathrm{mg} / \mathrm{ml}$. Proteus vulgaris the highest inhibition for chloroform extract was $16 \mathrm{~mm}$ at the concentration $(10,25,50,100) \mathrm{mg} / \mathrm{ml}$ and the lower at concentration was (5) $\mathrm{mg} / \mathrm{ml}$ with diameter $9 \mathrm{~mm}$, while for ethanol extract the highest inhibition zone at the concentration $(50,100) \mathrm{mg} / \mathrm{ml}$ with diameter $8 \mathrm{~mm}$ And the lower $(5,10) \mathrm{mg} / \mathrm{ml}$ with diameter $4 \mathrm{~mm}$. Staphylococcus aureus give the highest inhibition zone for chloroform with extract (25, $50,100) \mathrm{mg} / \mathrm{ml}$ diameter 14, 14, $17 \mathrm{~mm}$ respectively, and the lower (5) $\mathrm{mg} / \mathrm{ml}$ with diameter $4 \mathrm{~mm}$, while give for ethanol extract highest inhibition zone at the concentration (100) $\mathrm{mg} / \mathrm{ml}$ with diameter $7 \mathrm{~mm}$ and there was no inhibition zone at the concentration (5, $10,25,50) \mathrm{mg} / \mathrm{ml}$. Serratia marcescens gives the highest inhibition zone for chloroform extract at the concentration $(25,50,100)$ $\mathrm{mg} / \mathrm{ml}$ was $9 \mathrm{~mm}$ and at the lower concentration $(5,10) \mathrm{mg} / \mathrm{ml}$ there is no inhibition zone. And give for ethanol extract at the concentration $(100) \mathrm{mg} / \mathrm{ml} 12 \mathrm{~mm}$, and there was no inhibition zone at the concentration (5) $\mathrm{mg} / \mathrm{ml}$.

In the literature it was reported that the bioactive phytochemical compounds penetrate inside the cell, where they interfere with cellular metabolism ${ }^{(35)}$, and also that they react with active sites of enzymes or act as a $\mathrm{H}^{+}$ carrier, disturb the cellular membrane depleting adenosine triphosphate pool. It was found that antifungal resistance may depend on strain and source of isolation, species, genus (36), as well as on the active components in the leaf cherry extracts. Moreover, leaf composition and the solvents used in extract, origin and cultivars of plant, climate and harvesting time may affect the consequent antifungal properties (22,36). Phytochemical compound in stick sweet cherry extract and the solvents used extracts, may affect the antibacterial properties, plants and fruits could 
be that alternative because most of them are with few side effects and safe if any, they cost less and affect a wide range of resistant microorganisms.

\section{Acknowledgments}

The author grateful to Department of Applied Sciences and Biotechnology Division and very thankful to assistant professor Dr. Amani Abdul Wahhab Abdul Razzak for providing their kind support.

\section{Conflict of interest \\ None declare.}

\section{Funding}

Self-funding.

\section{References}

1. He FJ, Nowson CA, Lucas $M$, et al. increased consumption of fruit and vegetables is related to a reduced risk of coronary heart disease: Meta-analysis of cohort studies. J Hum Hypertens. 2007; 21(9): 71728. doi: 10.1038/sj.jhh.1002212.

2. Ferretti G, Bacchetti $T$, Belleggia $A$, et al. Cherry antioxidants: from farm to table. Molecules. 2010; 15(10): 6993-7005.

doi: 10.3390/molecules15106993.

3. Kirakosyan A, Seymour EM, Wolforth J, et al. Tissue bioavailability of anthocyanins from whole tart cherry in healthy rats. Food Chem. 2015; 171: 26-31. doi: 10.1016/j.foodchem.2014.08.114.

4. Seymour EM, Ou B. Phytochemical and diverse antioxidant profile of whole tart cherries (Prunus Cerasus). FASEB J. 2011; 25(Suppl 1): 773.14.

5. Rackova L, Oblozinsky $M$, Kostalova $D$, et al. Free radical scavenging activity and lipoxygenase inhibition of Mahonia aquifolium extract and isoquinoline alkaloids. J Inflammation (Lond), 2007, 4(1); 15-22. doi: 10.1186/1476-9255-4-15.

6. Seymour EM, Singer AAM, Bennink MR, et al. Cherryenriched diets reduce metabolic syndrome and oxidative stress in lean Dahl-SS rats. FASEB J. 2007; 21(5): 225-8.

7. Yiğit $D$, Yiğit N, Mavi A. Antioxidant and antimicrobial activities of bitter and sweet apricot (Prunus armeniaca L.) kernels. Braz J Med Biol Res. 2009; 42(4): 346-52. doi: http://dx.doi.org/10.1590/S0100879X2009000400006.

8. Whelton SP, Hyre AD, Pedersen B, et al. Effect of dietary fiber intake on blood pressure: a metaanalysis of randomized, controlled clinical trials. J Hypertens. 2005 Mar; 23(3):475-81.

9. Safari MR, Sheikh N. Effects of flavonoids on the susceptibility of low-density lipoprotein to oxidative modification. Prostaglandins Leukot Essent Fatty Acids. 2003; 69(1): 73-7.

10. Blando F, Gerardi C, Nicoletti I. Sour cherry (Prunus cerasus $\mathrm{L}$ ) anthocyanins as ingredients for functional foods. J Biomed Biotechnol. 2004; 2004(5): 253-8. doi: $10.1155 / \mathrm{S} 1110724304404136$.

11. Traustadóttir T, Davies SS, Stock AA, et al. Tart cherry juice decreases oxidative stress in healthy older men and women, J Nutr. 2009; 139(10): 1896-900. doi: 10.3945/jn.109.111716.

12. Saleem MMNM, Mohammad AAW, Al-Amiery AAH, et al. In vivo study of cherry stick effect on concentration of serum total cholesterol, triglyceride and total protein in white albino male mice. J Fac Med Baghdad. 2010; 52(3): 340-3.

13. Kim DO, Heo HJ, Kim YJ, et al. Sweet and sour cherry phenolics and their protective effects on neuronal cells. J Agric Food Chem. 2005; 53(26): 9921-7. doi: 10.1021/jf0518599.

14. Phillips KM, Tarrago -Trani MT, Gebhardt SE, et al. Stability of vitamin $C$ in frozen raw fruit and vegetable homogenates. J Food Composition Analysis. 2010; 23(3): 253-9. doi: 10.1016/j.jfca.2009.08.018.

15. Parvin P, Manouchehr B, Alireza G. An innovative method of dispersive three liquid micro extraction combined with HPLC-UV for the determination of vitamin B1 in sour cherry juice. Malaysian J Pharmaceut Sci. 2015; 13(1): 13-24.

16. Fazzari M, Fukumoto L, Mazza G, et al. In vitro bioavailability of phenolic compounds from five cultivars of frozen sweet cherries (Prunus avium L.). J Agric Food Chem. 2008; 56(10): 3561-8. doi: 10.1021/jf073506a.

17. Jacob RA, Spinozzi GM, Simon VA, et al. Consumption of cherries lowers plasma urate in healthy women. J Nutr. 2003; 133(6): 1826-9. doi: 10.1093/jn/133.6.1826.

18. Pearson TA, Mensah GA, Alexander RW, et al. Markers of inflammation and cardiovascular disease: application to clinical and public health practice. A statement for healthcare professionals from the Centers for Disease Control and Prevention and the American Heart Association. Circulation. 2003; 107: 499-511.

19. Ridker PM. C-reactive protein, inflammation and cardiovascular disease - Clinical Update. Tex Heart Inst J. 2005; 32: 384-6.

20. Sahan Y. Effect of Prunus laurocerasus L. (Cherry Laurel) leaf extracts on growth of bread spoilage fungi. Bulg J Agric Sci. 2011, 17(1): 83-92.

21. Lourenço FR, Pinto TJA. Comparison of three experimental designs employed in gentamicin microbiological assay through agar diffusion. Braz J Pharm Sci. 2009; 45(3): 559-66. doi: http://dx.doi.org/10.1590/S198482502009000300022.

22. Blando F, Gala R, Gerardi, et al. Sour cherry (Prunus Cerasus L.) production C. towards the utilization for $a$ 
new century. ISHS Acta Horticulturae 2004; 629: 458. doi: 10.17660/ActaHortic.2004.629.5.

23. Shih $\mathrm{PH}$, Yeh CT, Yen GC. Anthocyanins induce activation of phase II enzymes through the antioxidant response element pathway against oxidative stress-induced apoptosis. J Agric Food Chem. 2007; 55(23): 9427-35. doi: 10.1021/jf071933i.

24. Sarić A, Sobocanec S, Balog $T$, et al. Improved antioxidant and anti-inflammatory potential in mice consuming sour cherry juice (Pruns Cerasus cv. Maraska). Plant Foods Hum Nutr. 2009; 64(4): 231-7. doi: 10.1007/s11130-009-0135-y.

25. Piironen V, Lindsay DG, Miettinen TA, et al. Plant sterols: biosynthesis, biological function and their importance to human nutrition. J Sci Food Agric. 2000, 80: 939-66. doi: 10.1002/(SICI)10970010(20000515)80:7<939::AID-JSFA644>3.0.CO;2-C.

26. He YH, Zhou J, Wang YS, et al. Anti-inflammatory and anti-oxidative effects of cherries on Freund's adjuvant-induced arthritis in rats. Scand J Rheumatol. 2006; 35(5): 356-8. doi: 10.1080/03009740600704155.

27. Martin KR, Bopp J, Burrell L, et al. The effect of $100 \%$ tart cherry juice on serum uric acid levels, biomarkers of inflammation and cardiovascular disease risk factors. FASEB J. 2011; 25 (Meeting Abstract Supplement): 339.2 .

28. Haidari F Jr, Mohammad Shahi M, Keshavarz SA, et al. Inhibitory effects of tart cherry (Prunus cerasus) juice on xanthine oxidoreductase activity and its hypouricemic and antioxidant effects on rats. Malays J Nutr. 2009; 15(1): 53-64.

29. McDade TW. Early environments and the ecology of inflammation. Proc Natl Acad Sci U S A. 2012; 109 Suppl 2: 17281-8. doi: 10.1073/pnas.1202244109.

30. Kelley DS, Adkins Y, Reddy, et al. Sweet bing cherries lower circulating concentrations of markers for chronic inflammatory diseases in healthy humans. J Nutr. 2013; 143(3): 340-4. doi: 10.3945/jn.112.171371.

31. Manach C, Williamson G, Morand C, et al. Bioavailability and bioefficacy of polyphenols in humans. I. Review of 97 bioavailability studies. Am J Clin Nutr. 2005; 81(1 Suppl): 230S-242S. doi: 10.1093/ajcn/81.1.230S.

32. Haddy FJ, Vanhoutte PM, Feletou M. Role of potassium in regulating blood flow and blood pressure. Am J Physiol Regul Integr Comp Physiol. 2006; 290(3): R546-52. doi: 10.1152/ajpregu.00491.2005.

33. Adrogué HJ1, Madias NE. Sodium and potassium in the pathogenesis of hypertension. N Engl J Med. 2007; 356(19): 1966-78. doi: 10.1056/NEJMra064486.

34. Seymour EM, Kondoleon MG, Huang MG, et al. Tart cherry-enriched diets reduce atherosclerosis and mortality in mice. FASEB J. 2011; 25(Meeting Abstract Supplement): 980.10.

35. Marino M, Bersani C, Comi G. Impedanc measurements to study the antimicrobial activity of essential oils from Lamiaceae and Compositae. Int J Food Microbiol. 2001; 67(3): 187-95.

36. Farag RS, Daw ZY, Abo-Raya SH. Influence of some spice essential oils on Aspergillus parasiticus growth and production of aflatoxinsin a synthetic medium. Journal of Food Science. 1989; 54: 74-6. doi: 10.1111/j.1365-2621.1989.tb08571.x.

E-mail: mm.najeeb@yahoo.com
Received May 16 $16^{\text {th }} 2017$
Accepted Oct. $22^{\text {nd }} 2017$

